\title{
STRIDULATORY SOUND EMISSION OF Panstrongylus rufotuberculatus CHAMPION, 1899, (HEMIPTERA: REDUVIIDAE: TRIATOMINAE)
}

\author{
REYES-LUGO, M. ${ }^{1}$, DÍAZ-BELLO, Z. ${ }^{2}$, ABATE, T. ${ }^{3}$ and AVILÁN, A. ${ }^{1}$ \\ ${ }^{1}$ Medical Entomology Section, Institute of Tropical Medicine, Universidad Central de Venezuela, Caracas, Venezuela \\ ${ }^{2}$ Immunology Section, Institute of Tropical Medicine, Universidad Central de Venezuela, Caracas, Venezuela \\ ${ }^{3}$ Molecular Biology Section, Institute of Tropical Medicine, Universidad Central de Venezuela, Caracas, Venezuela \\ Correspondence to: Matias Reyes-Lugo, Medical Entomology Section, Institute of Tropical Medicine, \\ Universidad Central de Venezuela, POBox 40395, Caracas, 1040, Venezuela, e-mail: reyesr@ camelot.rect.ucv.ve \\ Received November 6, 2003 - Accepted September 28, 2004 - Distributed May 31, 2006
}

(With 1 figure)

\begin{abstract}
This study contains the first report of stridulatory sound observed in Panstrongylus rufotuberculatus Champion, 1899, and also a new record of this species in Venezuela. The conditions in which stridulation occurred are described, as well as the general environmental characteristics of the localities where it was found. This triatomine only performs the sound in conditions of extreme provocation.
\end{abstract}

Keywords: stridulation, sound, Panstrongylus rufotuberculatus, Triatominae, Venezuela.

\section{RESUMO}

\section{Emissão de som estridulatório do Panstrongylus rufotuberculatus Champion, 1899, (Hemiptera: Reduviidae: Triatominae)}

Este estudo contém o primeiro reporte da estridulação observada em Panstrongylus rufotuberculatus Champion, 1899, e um novo registro desta espécie na Venezuela. Descrevem-se as condições em que ocorre a estridulação, como também as características gerais das localidades onde foi capturado. Este triatomino só emite som em condições de extrema provocação.

Palavras-chave: estridulação, som, Panstrongylus rufotuberculatus, Triatomíneo, Venezuela.

\section{INTRODUCTION}

Stridulation occurs widely in Heteroptera, involving many different parts of the body and varying with the species (Chapman, 1998). In Reduviidae, (Hemiptera) the stridulatory system consists of a file of sulcus in the prosternum, with the tip of the rostrum forming the scraper. Stridulatory sulcus, the general shape, pilosity, the cuticular structure and the edges, as well as certain characteristics of the parallel groves, can be used for taxonomic purposes (Carcavallo et al., 1998). It has been suggested that sound emission in insects plays a role in gender identification during copulation (Chapman, 1998). In the case of Triatominae, it has been established that such emissions are part of the intraspecific communication mechanisms
(Schofield, 1977); for example, females that are nonreceptive to T. infestans Klug, 1834 or $R$. prolixus Stal, 1859 use sound to reject males (Manrique \& Lazzari, 1994; Manrique \& Schilman, 2000). The stridulation may act as a mechanism for repelling potential predators (Leston, 1957), defensive behaviour or recognition between sex, for example in $R$. prolixus can indicated female reject males or defensive. The meaning keeps a relationship with the intensity and frequency of stridulatory sound, and this with inter-ridge distances on stridulatory grooves (Manrique \& Schilman, 2000; Schilman et al., 2001).

The present study is the first record of audible sound in Panstrongylus rufotuberculatus Champion, 1899. 


\section{MATERIALS AND METHODS}

During the capture of Panstrongylus geniculatus Latreille, 1811 in El Hatillo, Miranda State (Reyes-Lugo et al., 2001), a male specimen of Panstrongylus rufotuberculatus Champion, 1899 was obtained at $22 \mathrm{~h}$ on may 04, 2001 near a light outside one of the buildings at the study site, and was kept alive in the laboratory for several days. A second male, which had been collected in the same way in San Diego de Los Altos in May 1999 and preserved since then in 70\% etanol, has been included in this study. Identification of the specimens was carried out using the Triatominae keys of Ramiréz-Pérez (1985) and Carcavallo et al. (1998). Morphological studies of the stridulatory organ of both samples were realized with a Hitachi S-450 scanning electron microscopy. In addition the material was protected from breakage by using low acceleration $(25 \mathrm{Kv})$.

\section{RESULTS}

When the live specimen of $P$. rufotuberculatus was held with a pincer by the thorax in a ventral position in order to extract a sample of faeces with a view to detecting the presence of Trypanosoma cruzi, the insect emitted a sound similar to that produced by sandpaper scraping wood. Part of the stridulatory organ can be seen in a photograph obtained with the scanning electron microscopy at 100x (Fig.1)

\section{DISCUSSION}

It could be confirmed that the stridulatory emission by $P$. rufotuberculatus was produced by a similar vibration to that described for $T$. infestans Klug, 1834 (Schofield, 1979), in other words by rubbing the tip of the reflexed proboscis along the transversely ridged prosternal groove with an anterior-posterior movement; the return stroke, posterior-anterior, is silent (Schofield, 1977). This vibratory movement was only observed when the sample was held with the pincer in the abovementioned position, and it only lasted about five minutes, although the insect remained immobile for a longer period. In the silence of the laboratory, the stridulation was audible up to about one meter away. The sound emitted by $P$. rufotuberculatus in the laboratory only when held with a pincer in a ventral position, matches that reported in the case of other triatominae when submitted to conditions of extreme provocation such as the attack of a predator (e.g., Leston, 1957; Schofield, 1979).

Although all Triatominae have a stridulatory organ, it seems that in the majority of species the sound has never been percieved by human ear (Mazzotti, 1970). Up to now only Dipetalogaster maxima Uhler, 1894 (Mazzotti, 1970; Schilman et al., 2001), Triatoma infestans Klug, 1834; T. guasayana Wygodzinsky \& Abalos, 1949; T. sordida Stal, 1859; (Schilman et al., 2001), Panstrongylus megistus Burmeister, 1835; (Schofield, 1977) and Rhodnius prolixus Stal, 1859

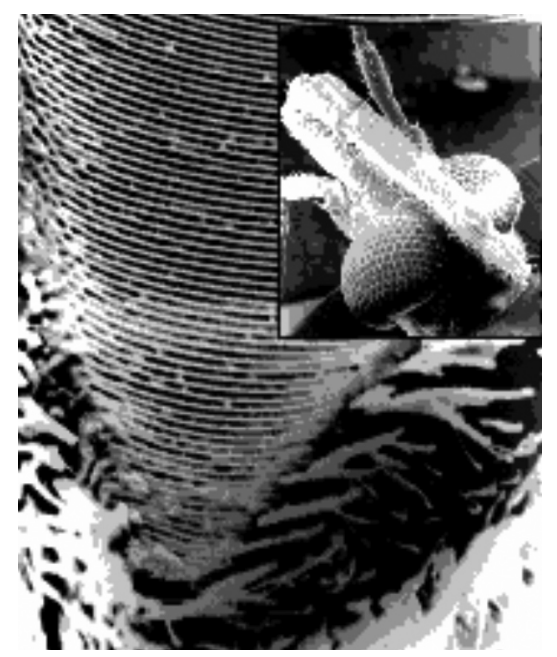

Fig. 1 - P. rufotuberculatus Champion 1899, photograph of the stridulatory organ at 100x; upper right insert showing the cephalic region (30x). Taken with Hitachi S-450 Scanning Electron Microscopy (acceleration $25 \mathrm{Kv}$ ). 
(Manrique \& Schilman, 2000; Schilman et al., 2001) have been described when disturbed or handled.

$P$. rufotuberculaus is found in Argentina, Bolivia, Brazil, Colombia, Costa Rica, Ecuador, Mexico, Panama, Peru and Venezuela (Schofield, 1994, Salomón et al., 1999). In the municipality of Amalfi in Antioquia, Colombia, P. rufotuberculatus is considered a high epidemiological risk for the transmission of Trypanosoma cruzi and represents $47 \%$ of captured triatomine, constituting the second most common reduvid caught inside buildings (Wolf et al., 2001). Likewise this triatomine has been reported in domestic environments in Peru, Bolivia and south of Ecuador (Abad-Franch et al., 2001). Adults of this species are attracted by lights on walls outside houses (Salomón et al., 1999; Abad-Franch et al., 2001). In Costa Rica P. rufotuberculatus can be found from sea level to $1,450 \mathrm{~m}$, but seems to be more common at levels below $800 \mathrm{~m}(74.1 \%)$ and especially below $200 \mathrm{~m}$ (52.5\% of the specimens); it tends to be more common during the first six months of the year (dry season and beginning of the rainy season) (Zeledón et al., 2001).

In Bolivia four nymphs and one adult of P. rufotuberculatus were found colonizing a house located in a forest environment; it has also been found in Bolivia at altitudes that range between 1,500 to 2,600 m (Noireau et al., 1994). This species has been found associated with wild mammals (kinkajous, bats and opossums) and adult specimens have been observed occasionally in human dwellings in Ecuador, Peru and Bolivia (Zeledón et al., 2001).

In Venezuela, $P$. rufotuberculatus has rarely been collected although it has been reported throughout most of the country, namely in the states of Aragua, Carabobo, Cojedes, Distrito Federal, Falcón, Guarico, Lara, Monagas, Portuguesa, Sucre, Tachira, Trujillo, Yaracuy, Zulia, Territorio Delta Amacuro and Territorio Amazonas (Lent \& Pifano, 1940, Cova-García \& Suarez, 1959, Ramírez-Pérez, 1985). The findings in El Hatillo and San Diego de Los Altos are the first record of this species in Miranda State. Both places are about $25 \mathrm{~km}$ from Caracas, the former to the Southwest and the latter to the Southeast of the capital, and are located in the same region where Panstrongylus geniculatus Latreille, 1811 was first discovered to be colonizing domestic environments (Reyes-Lugo \& Rodríguez-Acosta, 2000).

The small towns of El Hatillo and San Diego de Los Altos, in the highlands of Miranda State, are spread out in what was until recently transition cloud forest at a height of 1,000 to 1,300 m (Ewel et al., 1976), but which has been deeply modified by housing construction and asphalted roads. Thus, El Hatillo and San Diego de Los Altos essentially comprise a mosaic of forest areas and secondary savannahs of different dimensions. In the wooded areas there are still trees characteristic of humid and cloud forests, such as those belonging to the Inga spp., Cressopia spp., Samanea spp. and Erythrina spp. genera among others; while in the secondary savannahs there are 17 species of plants from nine families - Graminae (Panicum maximum, Trachipogum hexandra, Andropogum bicornis, Stipa sp., Melinetum minutiflora), Compositae (Ichtyothere terminalis, Archirocline vargasiana), Melastomataceae (Miconia sp.), Papilonaceae (Crotalaria stipularis), Rubiaceae (Borreria sp., Coccocypselum lanceolatum, Declieuxia fructicosa), Scrophulariaceae (Capraria biflora), Labiatae (Hyptis mutabilis), Convolvulaceae (Ipomoea ochracea, Evolvulus sp.) and Papilionaceae (Phaseolus sp.) (Vareschi, 1968; Steyermark \& Huber, 1978). The mean annual temperature, relative environmental humidity and precipitation in the highlands of Miranda State are $21{ }^{\circ} \mathrm{C} \pm 2,85 \% \pm 10$ and $2000 \mathrm{~mm}$ respectively (Anonymous, 1998).

At the present the biological and P. C. R. analysis characterization of trypanosome isolated from the faeces of $P$. rufotuberculatus corresponds to T. cruzi (Díaz-Bello et al., 2002). These results are relevant because in Venezuela many aspects of the biology, ecology and behavior of this triatomine remain unknown.

Acknowledgments - We wish to thank the technician Milagros Díaz from the Electron Microscopy Department of the Odontology Faculty, Universidad Central de Venezuela, for her invaluable help during the scanning session and photographic processing, and Dr. Mirian Strauss from the Institute of Tropical Medicine, Cardiology Section, at the same university, for her suggestions.

\section{REFERENCES}

ABAD-FRANCH, F., PAUCAR, C. A., CARPIO, C. C., CUBA CUBA, C. A., AGUILAR, V. H. M. \& MILLES, M. A., 2001, Biogeography of Triatominae (Hemiptera: Reduviidae) in 
Ecuador: Implications for the design of control strategies. Mem. Inst. Oswaldo Cruz, 96: 611-620.

ANONYMOUS, 1998, Oficina Central de Información (OCI), pp. 1-169. In: Anuario estadístico de Venezuela.(Editors), Caracas, Venezuela: Taller Gráfico O. C. E. I.

CARCAVALLO, R. U., GALÍNDEZ GIRÓN, I., JURBERG, J., GALVAO, C. \& LENT, H., 1998, Pictorial keys for tribes, genera and species of the subfamily Triatominae, pp. 107-204. In: R. U. Carcavallo, I. Galindez Girón, J. Jurberg and H. Lent. (eds.), Atlas of Chaga's disease vectors in the Americas, $1^{\circ}$ vol., 393p., Cap. 4, Editora Fiocruz.

CHAPMAN, R. F., 1998, The Insects, structure and function. Cambridge University Press, $4^{\text {th }}$ Edition. 770p.

COVA-GARCÍA, P. \& SUAREZ, M. A., 1959, Estudio de los triatominos en Venezuela. Publicaciones de la División de Malariología $N^{\circ} 11$. Ministerio de Sanidad y Asistencia Social, Caracas, Venezuela. Tip. Vargas, S.A Caracas. 209p.

DÍAZ-BELLO, Z., RUÍZ, L., ABATE, T., REYES-LUGO, M., SÁNCHEZ, M. \& MAEKELT, A., 2002, Identificación y caracterización biológica de Tripanosomas aislados de Panstrongylus rufotuberculatus Champion 1899, capturados en el estado Miranda, Venezuela. Libro Resúmenes LII Convención Anual de AsoVAC. Barquisimeto Estado Lara, 17 al 22 de noviembre del 2002.

EWEL, J. J., MADRIZ, A. \& TOSI, J. A., 1976, Zonas de vida de Venezuela. Memoria explicativa sobre el mapa ecológico, pp. 1-270. In: Ministerio de Agricultura y Cría. (Editors). Caracas: Fondo Nacional de Investigaciones Agropecuarias.

LENT, H. \& PIFANO, F., 1940, Sobre a identidade dos géneros Panstrongylus Berg, 1879, e Mestor Kirkaldy, 1904. Redescricao de P. rufotuberculatus encontrado na Venezuela, naturalmente infestado pelo Schizotrypanum cruzi. Rev. Ent. Río de Janeiro, 11: 629-639.

LESTON, D., 1957, The stridulatory mechanisms in terrestrial species of Hemiptera Heteroptera. Proc. Zool. Soc. Lond., 128: 369-386.

MAZZOTI, L., 1970, Ausencia de emanaciones odoriferas perceptibles en Dipetalogaster maximus. Algunos comentarios sobre esta especie. Rev. Inst. Med. Trop. São Paulo, 12: 320-324.

MANRIQUE, G. \& LAZZARI, C. R., 1994, Sexual behaviour and stridulation during mating in Triatoma infestans (Hemiptera: Reduviidae). Mem. Inst. Oswaldo Cruz, 89: 629-633.

MANRIQUE, G. \& SCHILMAN, P. E., 2000, Two different vibratory signals in Rhodnius prolixus (Hemiptera: Reduviidae). Acta Tropica, 77(3): 271-278.

NOIREAU, F., BOSSENO, M. F., VARGAS, F. \& BRENIÈRE, S. F., 1994, Apparent trend to domesticity observed in Panstrongylus rufotuberculatus Champion, 1899 (Hemiptera: Reduviidae) in Bolivia. Res. Rev. Parasitol, 54: 263-264.

RAMIRÉZ-PÉREZ, J., 1985, Chipos de Venezuela. Publicación de la Dirección de Malariología y saneamiento Ambiental, Ministerio de Sanidad y Asistencia Social, 108p.

REYES-LUGO, M. \& RODRÍGUEZ-ACOSTA, A., 2000, Domiciliation of selvatic Chagas disease vector Panstrongylus geniculatus Latreille, 1811 (Triatominae: Reduviidae) in Venezuela. Trans. of the R. Soc. of Trop. Med. and Hyg. 94: 508.

REYES-LUGO, M., DÍAZ-BELlO, Z., ABATE, T., MAEKELT, A. \& AVILÁN, A., 2001, Identification of Trypanosomes in Panstrongylus geniculatus Latreille, 1811 (Triatominae: Reduviidae) collected in El Hatillo town, Miranda State, Venezuela. 3erd. International Congress of Vector Ecology. Barcelona, Spain. Abstract, 1(33): 29- 80.

SALOMÓN, O. D., RIPIO, C. M., RIVETTI, E. \& CARCAVALLO, R. U., 1999, Presence of Panstrongylus rufotuberculatus (Champion, 1899) (Hemiptera: Reduviidae: Triatominae) in Argentina. Mem. Inst. Oswaldo Cruz, 94: 285-288.

SCHILMAN, P. E., LAZARRI, C. R. \& MANRIQUE, G., 2001, Comparasion of disturbance stridulations in five species of triatominae bugs. Acta Tropica, 79(2): 171-178.

SCHOFIEL, D. C. J., 1977, Sound production in some triatomine bugs. Physiol. Ent., 2: 43-52, 1977.

SCHOFIEL, D. C. J., 1979. The behaviour of Triatominae (Hemiptera: Reduviidae): review. Bull. Of Entom. Res., 69: 363-379.

SCHOFIELD, C. J., 1994, Triatominae: Biología y Control. Zeneca Public Health. Eurocommunica Publications. UK. 80p.

STEYERMARK, J. A. \& HUBER, O., 1978, Flora del Avila. Flora y vegetación de la montaña del Avila, de la Silla y del Naiguatá. Caracas: Sociedad Venezolana de Ciencias Naturales y Ministerio el Ambiente y de los Recursos Naturales Renovables, pp. 1-971.

VARESCHI, V., 1968, Sabanas del Valle de Caracas. Estudio de Caracas. Ediciones de la Biblioteca Central de la Universidad Central de Venezuela, 1: 17-119.

WOLF, M., CASTILLO, D., URIBE, J., \& ARBOLEDA, J. J., 2001, Tripanosomiasis americana: determinación de riesgo epidemiológico de transmisión en el municipio de Amalfi, Antioquia. IATREIA, 14(2): 111-121.

ZELEDÓN, R., J. A. UGALDE \& PANIAGUA, L. A., 2001, Entomological aspects of six sylvatic species of triatomines (Hemiptera, Reduviidae) from the collection of the National Biodiversity Institute of Costa Rica, Central America. Mem. Inst. Oswaldo Cruz, 96: 757-764. 